\title{
Re-evaluation of the classical Mycoplasma lipophilum cluster (Weisburg et al. 1989) and description of two new clusters in the hominis group based on 16S rDNA sequences
}

\author{
Bertil Pettersson, ${ }^{1}$ Joseph G. Tully, ${ }^{2} \dagger$ Göran Bölske ${ }^{3}$ \\ and Karl-Erik Johansson ${ }^{3}$
}

1 Department of

Biotechnology, The Royal

Institute of Technology,

S-100 44 Stockholm,

Sweden

2 Mycoplasma Section, Frederick Cancer Research and Development Center, National Institute of Allergy and Infectious Diseases, Frederick, MD 21702, USA

3 Department of Bacteriology, National Veterinary Institute, S-751 89 Uppsala Sweden

\author{
Author for correspondence: Bertil Pettersson. Tel: +46879082 87. Fax: +46 8245452 \\ e-mail: bertil@ biochem.kth.se
}

The Mycoplasma lipophilum cluster (Weisburg et al. 1989) in the hominis group of the mollicutes is re-evaluated in this work to update the phylogenetic framework for classification of species within the genus Mycoplasma. Therefore, sequences of the 16S rRNA gene were determined from previously described species, and $\mathbf{1 1}$ were found to be closely related to the M. lipophilum cluster. A selection of members of the other hitherto defined clusters of the hominis group was included for phylogenetic analysis, revealing that the classical M. lipophilum cluster could be re-organized into two clusters, namely the M. lipophilum cluster and the Mycoplasma bovis cluster. The former was found to contain two species, while the latter contained 20 species. The two clusters were closely related, sharing an ancestral branch with the Mycoplasma synoviae cluster. Furthermore, the $M$. bovis cluster could be divided into subclusters. Interestingly, two species, Mycoplasma equigenitalium and Mycoplasma elephantis, formed a distinct and early branch of the $M$. lipophilum, M. bovis and $M$. synoviae clusters. This entity was termed the $M$. equigenitalium cluster. The clusters and subclusters could be verified by using neighbour-joining and maximum-likelihood analyses on a variety of data sets, bootstrap calculations, secondary structure analysis and signature nucleotides. Therefore, the new 16S rDNA data presented in this work were used to reevaluate the $M$. lipophilum cluster, leading to the definition of two additional clusters. At present, the mollicutes belonging to the hominis group can be classified into ten evolutionary lineages.

Keywords: $16 \mathrm{~S}$ rRNA, hominis group, Mollicutes, Mycoplasma lipophilum cluster, phylogeny

\section{INTRODUCTION}

The class Mollicutes (trivial name mycoplasmas) evolved from the Clostridium-Streptococcus-Lactobacillus branch of the phylum harbouring Gram-

\footnotetext{
† Present address: 16400 Black Rock Rd, Germantown, MD 20874-3212, USA.

Abbreviations: FCB, Flavobacterium-Cytophaga-Bacteroides division; $\mathrm{ML}$, maximum-likelihood; NJ, neighbour-joining

The GenBank accession numbers for the 16S rRNA gene sequences determined in this paper are AF221111-AF221121.
}

positive organisms with a low $\mathrm{G}+\mathrm{C}$ content in their genomes (Maniloff, 1992). A sparse array of biochemical features characterizes the mollicutes and the use of molecular data is important for taxonomic work on these micro-organisms (ICSB Subcommittee on the Taxonomy of Mollicutes, 1995; Heldtander et al., 1998; Lee et al., 1998; Pettersson et al., 2000; Weisburg et al., 1989). At present, the mollicutes contain five distinct phylogenetic groups, as revealed by analysing the primary structures of the $16 \mathrm{~S}$ rRNA molecule (Weisburg et al., 1989). The major group is the socalled hominis group, which was named after the human mollicute Mycoplasma hominis. The hominis 
group has been subdivided into eight sublineages (clusters and branches containing single species) by Weisburg et al. (1989) and Pettersson et al. (1996, 2000).

Many species of the genus Mycoplasma have been described, primarily by serological methods, but without determining the actual evolutionary relationship to other mollicutes. The aim of the present study was to investigate the current status of the Mycoplasma lipophilum phylogenetic cluster based on 16S rRNA gene sequences. The following species of the genus Mycoplasma were sequenced and found to belong to the $M$. lipophilum cluster or to form a new cluster within the phylogenetic hominis group. Mycoplasma caviae $\left(\mathrm{G} 122^{\mathrm{T}}\right)$ was first isolated from different tissues of guinea pigs by Hill (1971). Although one strain of this species was associated with uterine infection, it is not known whether the species is pathogenic. Mycoplasma columbinasale $\left(694^{\mathrm{T}}\right)$ was first isolated by Yoder \& Hofstad (1964) from pigeon nasal turbinates and its taxonomic status was later established by Jordan et al. (1982). Mycoplasma columbinum (MMP-1 ${ }^{\mathrm{T}}$ ) was first isolated from the oropharynx and trachea of pigeons and described by Shimizu et al. (1978). Whether this organism is pathogenic has not been established. A collection of mycoplasmas isolated from the respiratory tract of chickens, all apparently non-pathogenic, was examined by Edward \& Kanarek (1960) and designated as Mycoplasma iners. An almost complete 16S rDNA sequence has been deposited under the accession number AF064063. However, the strain designation of the isolate associated with this sequence is uncertain and the established type strain, PG30 ${ }^{\mathrm{T}}$ (Edward \& Freundt, 1973), was therefore selected for sequencing in this work. Mycoplasma lipofaciens $\left(\mathrm{R} 171^{\mathrm{T}}\right)$ was first isolated from the infra-orbital sinus of a chicken and described by Bradbury et al. (1983). Again, pathogenicity has not been established. Mycoplasma maculosum was first isolated by Edward \& Fitzgerald (1951) from the throat and genital tracts of dogs and designated as strain $\gamma$. Later, Edward \& Freundt (1956) established its taxonomic status and designated $\mathrm{PG} 15^{\mathrm{T}}$ as the type strain. Mycoplasma strains isolated from the canine throat and bladder by Armstrong et al. (1970) were characterized as members of a putative new species (canine serogroup D). Rosendal (1975) introduced a new species, Mycoplasma opalescens $\left(\mathrm{MH} 5408^{\mathrm{T}}\right)$, collectively classifying these strains. The human Mycoplasma sp. strain Navel and related simian mycoplasmas were named $\mathrm{Myco-}$ plasma primatum by DelGiudice et al. (1971). The simian strain $\mathrm{HRC} 292^{\mathrm{T}}$ was selected as the type strain. A partial 16S rDNA sequence (about $900 \mathrm{bp}$ ) of $M$. primatum strain Navel (not the type strain) has been deposited in GenBank by Rawadi et al. (1998). Mycoplasma spermatophilum was isolated from sperm and cervical specimens of patients with infertility problems (Hill, 1991). A partial sequence of $M$. spermatophilum strain $\mathrm{AH} 159^{\mathrm{T}}$ (about $900 \mathrm{bp}$ ) has been deposited in GenBank by Rawadi et al. (1998).
Mycoplasma strains isolated from the cervix of mares by Krabisch et al. (1973) were later classified as Mycoplasma equigenitalium $\left(\mathrm{T} 37^{\mathrm{T}}\right)$ by Kirchhoff (1978). Mycoplasma elephantis (E42 ${ }^{\mathrm{T}}$ ) was first isolated from the genital tract of female elephants by Clark et al. (1978) and later characterized by Kirchhoff et al. (1996). Pathogenicity has not been established for either M. equigenitalium or M. elephantis.

The phylogenetic analysis presented in this work reveals that species showing close relationships to $M$. lipophilum can be grouped into new and revised clusters.

\section{METHODS}

Bacterial strains, growth conditions and preparation of genomic DNA. All strains sequenced in this study were obtained from the mycoplasma culture collection at the National Veterinary Institute in Uppsala, Sweden, and from the former mycoplasma culture collection at the Mycoplasma Section of the National Institute of Allergy \& Infectious Diseases in Frederick, MD, USA (Table 1). The mycoplasmas were grown in appropriate media as described previously (Bölske, 1988). The cells were washed three times in PBS and DNA was prepared by phenol-chloroform extraction according to standard procedures (Johansson et al., 1998b).

Determination of $16 \mathrm{~S}$ rDNA sequences. Genomic DNA (10 ng) was used for amplification of virtually complete 16S rRNA genes with primers RIT593 and RIT620B. In order to increase yield and specificity, the PCR products obtained were subjected to two different semi-nested amplifications by using $1 \mu \mathrm{l}$ of the product as template in the subsequent reactions. Primers RIT593 and RIT390B were used in one of the amplifications and RIT388 and RIT620B were used in the other semi-nested reaction. All PCR primers have been published previously (Pettersson et al., 1996). The first set covered the U1 to U5 regions (Gray et al., 1984) of the 16S rRNA gene and the second set defined the segment between the $\mathrm{U} 2$ and $\mathrm{U} 8$ regions. Biotinylated PCR products, suitable for solid-phase DNA sequencing, were generated with $10 \mathrm{pmol}$ of each primer. The following thermo-cycling profile was used in all amplifications. Denaturation at $96^{\circ} \mathrm{C}$ for $15 \mathrm{~s}$ and a combined primer annealing/extension step at $70{ }^{\circ} \mathrm{C}$ for $90 \mathrm{~s}$ was repeated 30 times. A final extension at $72{ }^{\circ} \mathrm{C}$ for $10 \mathrm{~min}$ was also used. One primer was biotinylated in each of the two sets in order to generate products suitable for solid-phase $16 \mathrm{~S}$ rDNA sequencing. Immobilization of the biotinylated PCR products followed by strand separation and template preparation were performed with superparamagnetic beads (Dynabeads M-280 Streptavidin) according to the instructions of the manufacturer (Dynal AS). The nucleotide sequences from both strands were determined by direct solid-phase $16 \mathrm{~S}$ rDNA sequencing using protocols and primers detailed previously (Johansson et al., 1998a; Pettersson et al., 1996).

Phylogenetic analysis. The sequences were aligned manually by using the Genetic Data Environment (GDE) software (Smith, 1992). A set of differently modified alignments was obtained by the removal of gaps and ambiguously aligned positions and by excluding positions that were less than $50 \%$ conserved. The non-corrected and corrected alignments were used to establish evolutionary relationships 
Table 1 Species and strains belonging to the M. bovis, M. lipophilum and M. equigenitalium clusters

Sequences with the following accession numbers were also used in the phylogenetic analysis: 'Candidatus Mycoplasma ravipulmonis' (AF001173), 'Mycoplasma agassizii' PS6 (U09786), Mycoplasma alkalescens D12 ${ }^{\mathrm{T}}$ (U44764), Mycoplasma bovirhinis PG43 ${ }^{\mathrm{T}}$ (U44766), Mycoplasma conjunctivae HRC581 ${ }^{\mathrm{T}}$ (U44770), Mycoplasma felis $\mathrm{CO}^{\mathrm{T}}$ (U09787), Mycoplasma gallinaceum $\mathrm{DD}^{\mathrm{T}}$ (L24104), Mycoplasma gypis B1/T1 ${ }^{\mathrm{T}}$ (AF125589), M. hominis $\mathrm{PG} 21^{\mathrm{T}}$ (AJ002265), Mycoplasma hyorhinis BTS7

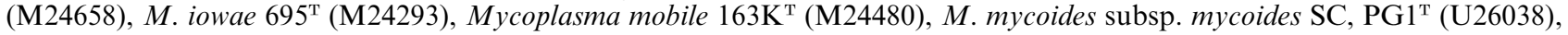
Mycoplasma neurolyticum Type A ${ }^{\mathrm{T}}$ (M23944), Mycoplasma ovipneumoniae $\mathrm{Y}^{\mathrm{T}} \mathrm{8}^{\mathrm{T}}$ (U44771), M. pneumoniae $\mathrm{FH}^{\mathrm{T}}$ (M29061), Mycoplasma pulmonis PG34 ${ }^{\mathrm{T}}$ (AF125582), Mycoplasma salivarium PG20 ${ }^{\mathrm{T}}$ (AF125583), Mycoplasma sualvi Mayfield B ${ }^{\mathrm{T}}$ (M23936) and M. synoviae WVU $1853^{\mathrm{T}}$ (L07757).

\begin{tabular}{|c|c|c|c|c|}
\hline Species and strain & Main host & Glu/Arg* & Accession no. $\dagger$ & Reference \\
\hline M. adleri $\mathrm{G}-145^{\mathrm{T}}$ & Goat & $-/+$ & U67943 & Heldtander et al. (1998) \\
\hline M. agalactiae $\mathrm{PG} 2^{\mathrm{T}}$ & Goat, sheep & $-/-$ & U44763 & Pettersson et al. (1996) \\
\hline M. bovigenitalium $\mathrm{PG} 11^{\mathrm{T}}$ & Cattle & $-1-$ & M24291 & Weisburg et al. (1989) \\
\hline M. bovis Donetta ${ }^{\mathrm{T}}$ & Cattle & $-1-$ & U44767 & Pettersson et al. (1996) \\
\hline M. californicum ST-6 ${ }^{\mathrm{T}}$ & Cattle & $-1-$ & M24582 & Weisburg et al. (1989) \\
\hline M. caviae $\mathrm{G} 122^{\mathrm{T}}$ & Guinea pig & $+/-$ & AF221111 & This study \\
\hline M. columbinasale $694^{\mathrm{T}}$ & Bird (pigeon) & $-/+$ & AF221112 & This study \\
\hline M. columbinum $\mathrm{MMP}-1^{\mathrm{T}}$ & Bird (pigeon) & $-/+$ & AF221113 & This study \\
\hline M. felifaucium $\mathrm{PU}^{\mathrm{T}}$ & Puma & $-/+$ & U15795 & Brown et al. (1995) \\
\hline M. fermentans $\mathrm{PG} 18^{\mathrm{T}}$ & Human, primate & $+/+$ & M24289 & Weisburg et al. (1989) \\
\hline M. gallinarum $\mathrm{PG} 16^{\mathrm{T}}$ & Bird (chicken, goose) & $-/+$ & L24105 & Boyle \& Morrow (1994) \\
\hline M. iners $\mathrm{PG} 30^{\mathrm{T}} \ddagger$ & Bird (chicken) & $-/+$ & AF221114 & This study \\
\hline M. leopharyngis $\mathrm{LL}^{\mathrm{T}}$ & Lion & $-1-$ & U16760 & Brown et al. (1995) \\
\hline M. lipofaciens $\mathrm{R} 171^{\mathrm{T}}$ & Bird (chicken) & $+/+$ & AF221115 & This study \\
\hline M. maculosum $\mathrm{PG} 15^{\mathrm{T}}$ & Dog & $-/+$ & AF221116 & This study \\
\hline M. meleagridis $17529^{\mathrm{T}}$ & Bird (turkey) & $-/+$ & L24106 & Boyle \& Morrow (1994) \\
\hline M. opalescens MH5408 & Dog & $-/+$ & AF221117 & This study \\
\hline M. primatum $\mathrm{HRC} 292^{\mathrm{T}}$ & Human, primate & $-/+$ & AF221118 & This study \\
\hline M. simbae $\mathrm{LX}^{\mathrm{T}}$ & Lion & $-/+$ & U16323 & Brown et al. (1995) \\
\hline M. spermatophilum $\mathrm{AH} 159^{\mathrm{T}}$ & Human & $-/+$ & AF221119 & This study \\
\hline M. hyopharyngis $\mathrm{H} 3-6 \mathrm{BF}^{\mathrm{T}}$ & Pig & $-/+$ & U58997 & Blank et al. (1996) \\
\hline M. lipophilum $\mathrm{MaBy}^{\mathrm{T}}$ & Human, primate & $-/+$ & M24581 & Weisburg et al. (1989) \\
\hline M. equigenitalium $\mathrm{T} 37^{\mathrm{T}}$ & Horse & $+1-$ & AF221120 & This study \\
\hline M. elephantis $\mathrm{E} 42^{\mathrm{T}}$ & Elephant & $+/-$ & AF221121 & This study \\
\hline
\end{tabular}

* Glu indicates glucose fermentation and Arg denotes arginine hydrolysis. +, Positive; -, negative.

$\dagger$ Accession numbers in bold indicate almost-complete 16S rDNA sequences determined in this study.

IA 16S rDNA sequence for $M$. iners was deposited in GenBank under the accession number AF064063. However, the strain designation was not available from this entry and the type strain was therefore resequenced in this work.

among the mollicutes investigated in this study. Phylogenetic calculations were performed by using algorithms implemented in the phylogenetic program package PHYLIP (Felsenstein, 1993). Infiles in the format compatible with that of PHYLIP were generated by using an option implemented in GDE. Both neighbour-joining (NJ) and maximum-likelihood (ML) programs were used to compute phylogenetic trees. Distances were corrected for multiple substitutions at single locations by the one-parameter model of Jukes \& Cantor (1969) and statistical evaluation was performed by resampling the data 1000 times. The F84 evolutionary model with empirical nucleotide frequencies and a transition/transversion ratio set to $2 \cdot 0$ (Felsenstein, 1993) were used to calculate evolutionary trees by ML. The option for global rearrangement was invoked to find the best tree.

Nucleotide sequence accession numbers. The $16 \mathrm{~S}$ rRNA gene sequences determined in this work have been deposited in GenBank. The accession numbers of these sequences and those retrieved for phylogenetic analysis are listed in Table 1.

\section{RESULTS AND DISCUSSION}

\section{$16 S$ rDNA sequences}

Primary structures of the $16 \mathrm{~S}$ rRNA molecule were determined for 11 previously described species (Table 1). Almost complete sequences were generated, as determined for both strands. Polymorphisms in the two 16S rRNA genes were found in the following strains: $M$. columbinum $\mathrm{MMP}-1^{\mathrm{T}}, \mathrm{A} / \mathrm{G}_{(193)} ; M$. caviae $\mathrm{G} 122^{\mathrm{T}}, \mathrm{A} / \mathrm{G}_{206}$ and $\mathrm{A} / \mathrm{G}_{224}$; and $M$. columbinasale $694^{\mathrm{T}}, \mathrm{C} / \mathrm{T}_{748}$ and $\mathrm{C} / \mathrm{T}_{1189}$ (according to Escherichia coli numbering; Brosius et al., 1978). The position in parentheses indicates that the corresponding position is absent from the $16 \mathrm{~S}$ rRNA gene of $E$. coli. All 
species studied in this work were found to have a uridine residue at position 912 in the 16S rRNA molecule. This is distinctive for members of the hominis group, occurring in a highly conserved locale of the 16S rRNA molecule, and it is observed rarely in the domain Bacteria (Pettersson et al., 1996, 2000; Weisburg et al., 1989). Therefore, $\mathrm{U}_{912}$ still proves to be synapomorphic for mollicutes of the hominis group.

\section{Phylogenetic analysis}

The sequences determined in this work were aligned with more than 300 other $16 \mathrm{~S}$ rDNA sequences from mollicutes. Phylogenetic trees were constructed with all operational taxonomic units (OTUs) contained in this alignment and the trees served as a guide for the selection of appropriate OTUs for a more detailed phylogenetic analysis of the $M$. lipophilum cluster. Representative mycoplasmas from all other hitherto defined clusters and lineages within the hominis group were included for proper analysis of the evolutionary relationships of the species studied in this work. Mycoplasma pneumoniae strain $\mathrm{FH}^{\mathrm{T}}$ and Mycoplasma iowae strain $695^{\mathrm{T}}$ belong to the pneumoniae group (Weisburg et al. 1989) and were included for comparison. The type species of the mollicutes, Mycoplasma mycoides subsp. mycoides $\mathrm{SC}$ strain $\mathrm{PG} 1^{\mathrm{T}}$, which is positioned phylogenetically in the spiroplasma group, served as an outgroup in the tree. Different criteria were applied in order to filter the data set for nucleotide positions to be used for phylogenetic analysis. By this procedure, subsets for final phylogenetic calculations were generated by removing gaps and ambiguously aligned positions and by applying a nucleotide consistency filter of $50 \%$, i.e. positions for which a certain nucleotide composition could not be observed in more than half of the sequences. The NJ and ML algorithms were used to analyse the resulting data sets and all trees showed overall agreement concerning topology; a representative evolutionary distance tree is displayed in Fig. 1. The tree was computed from a data set from which only gaps were removed, finally containing 1370 nucleotide positions. Alternative reference and outgroup organisms did not alter the topology of the tree significantly. The stability of the tree was tested statistically by bootstrap analysis and the percentage values as calculated from 1000 replicates are given at the individual nodes of the tree. The cladistic procedure revealed that the species studied in this work formed three distinct lines of descent, including a splitting of the classical $M$. lipophilum cluster (Weisburg et al., 1989) within the hominis group (Fig. 1).

\section{Phylogenetic considerations and nomenclature}

The inclusion of several mycoplasmas that have not previously been classified phylogenetically indicated clearly that the classical $M$. lipophilum cluster should be divided into two separate clusters. Consequently, the revised $M$. lipophilum cluster contained only two species, M. lipophilum and Mycoplasma hyopharyngis, and this reduced cluster bisects the Mycoplasma synoviae cluster and a clade that harbours 20 species, including the bovine pathogen Mycoplasma bovis (Fig. 1). A third entity to be considered in this work was found at the tip of an early branch of the M. synoviae, $M$. lipophilum and $M$. bovis clades. This entity was formed by $M$. equigenitalium strain $\mathrm{T} 37^{\mathrm{T}}$ and $M$. elephantis strain $\mathrm{E} 42^{\mathrm{T}}$; they showed a tight and distinct clustering in all trees.

Convincingly, certain nucleotide positions in the $16 \mathrm{~S}$ rRNA gene (Table 2) supported the lines of the new clusters. Moreover, a few of the positions were regarded as signatures and are shown in bold in Table 2. A signature nucleotide in this context is a nucleotide residue found explicitly in a certain position within the sequences of the particular cluster, where the base that is present differs from those found in the majority of the other prokaryote taxa. The clusters could also be defined by unique nucleotide positions in the 16S rRNA molecule (Table 2). The characterization of a unique nucleotide feature was restricted to the hominis group and/or the class Mollicutes. Thus, a nucleotide residue at a certain position was said to be unique when present in the molecules of all strains within the particular cluster and absent, with no or only a few exceptions, in the strains of any other cluster or group of the mollicutes. These features are useful as an aid in molecular phylogeny of the mollicutes for the evaluation of the validity of the groups, clusters and subclusters (Weisburg et al., 1989; Pettersson et al., 2000). Therefore, discriminative nucleotide information (detailed below) at defined positions further justifies the introduction of two new clusters within the hominis group. The two new phylogenetic clusters are named according to the binomial nomenclature, acquiring their epithets from a representative species in the respective cluster, as suggested for classificatory work based on molecular phylogeny of the mollicutes (Weisburg et al., 1989; Pettersson et al., 2000). Accordingly, the two new clusters will hereafter be referred to as the M. equigenitalium cluster and the $M$. bovis cluster, while the third lineage retains the name the $M$. lipophilum cluster, as introduced previously by Weisburg et al. (1989).

The statistical support and branch lengths suggested a shared common ancestry of the $M$. lipophilum, $M$. bovis and M. synoviae clusters (Pettersson et al., 1996), as indicated in Fig. 1. Moreover, these clusters possessed an apomorphic homologous structural feature between positions 722 and 723 (E. coli), with an extension of two extra bases. This attribute is found in the 16S rRNA molecule of neither the early branching M. equigenitalium cluster nor other mollicute groups or other taxa of the prokaryotes (Weisburg et al., 1989; Pettersson et al., 1996). It is likely that this idiosyncrasy was acquired somewhere on the ancestral branch of the $M$. lipophilum, $M$. bovis and $M$. synoviae clusters. The ancestral relationship was also reflected by the presence of derived nucleotide characters that were common to the three clusters, to the exclusion of 


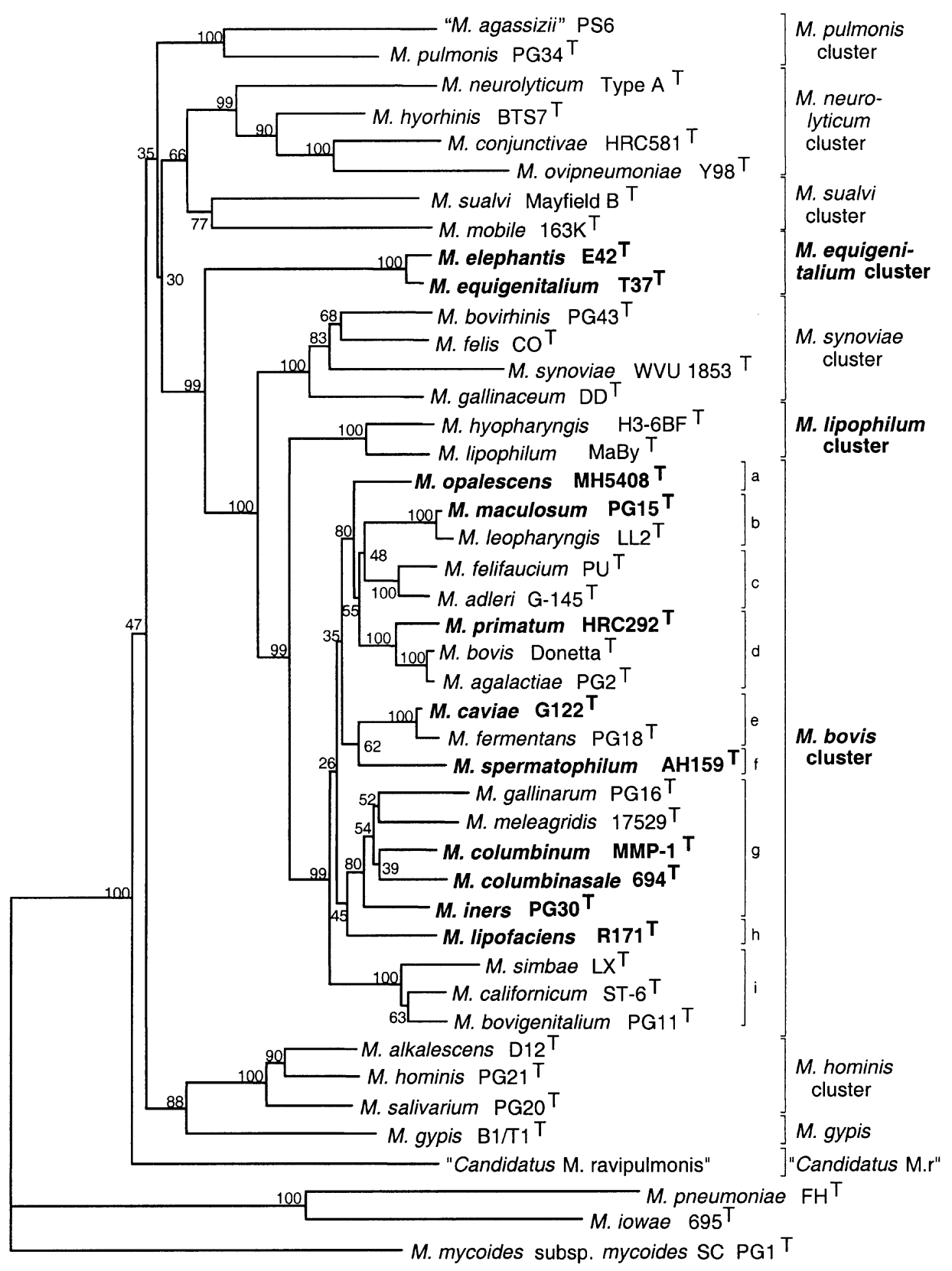

.10

Fig. 1. Evolutionary distance tree based on $16 \mathrm{~S}$ rRNA gene sequences, showing the representative phylogeny of the hominis group, but with emphasis on the $M$. equigenitalium, $M$. lipophilum and $M$. bovis clusters. The letters alongside vertical lines indicating subclusters of the $M$. bovis cluster correspond to the nomenclature used in the text and in Table 1. $M$. mycoides subsp. mycoides SC PG1 $1^{\top}$ of the spiroplasma group served as the outgroup and $M$. pneumoniae $\mathrm{FH}^{\top}$ and $M$. iowae $695^{\top}$, both belonging to the pneumoniae group of the mollicutes, were included for comparison. Bootstrap percentage values obtained from 1000 resamplings of the data set are given at the nodes. Clusters denoted in bold were introduced in this work and species in bold were sequenced in this work. The accession numbers of these sequences are given in Table 1 . The scale bar shows a distance equivalent to $0 \cdot 1$ substitutions per nucleotide position.

most other mollicutes. Among these positions were for example the canonical base pairs $\mathrm{U} \cdot \mathrm{A}$ and $\mathrm{A} \cdot \mathrm{U}$ in positions $612 \cdot 628$ and $833 \cdot 853$ (to be detailed elsewhere). Thus, the tree is likely to reflect a true evolutionary linking of the $M$. lipophilum, M. bovis and $M$. synoviae clusters.

\section{The M. lipophilum cluster}

Previously, the classical $M$. lipophilum cluster contained 11 characterized species (Weisburg et al., 1989; Pettersson et al., 1996; Heldtander et al., 1998). In this study, the M. lipophilum cluster has been revised, now 
The numbers of particular positions correspond to those in the 16S rRNA molecule of E. coli (Brosius et al., 1978). Signatures are shown in bold; lower-case letters denote residues found occasionally.

\begin{tabular}{|c|c|c|c|c|c|c|}
\hline $\begin{array}{l}\text { Position of } \\
\text { base or base pair }\end{array}$ & $\begin{array}{l}\text { M. equigenitalium } \\
\text { cluster }\end{array}$ & $\begin{array}{l}\text { M. lipophilum } \\
\text { cluster }\end{array}$ & $\begin{array}{l}\text { M. bovis } \\
\text { cluster }\end{array}$ & Hominis group & Mollicutes & Exceptions \\
\hline $129 \cdot 232$ & $\mathrm{U} \cdot \mathrm{G}$ & $\mathrm{U} \cdot \mathrm{G}$ & $\mathrm{C} \cdot \mathrm{G}$ & $\mathrm{U} \cdot \mathrm{G}$ & $\mathrm{C} \cdot \mathrm{G}, \mathrm{U} \cdot \mathrm{G}$ & \\
\hline $147 \cdot 175$ & $\mathrm{G} \cdot \mathrm{C}$ & $\mathbf{A} \cdot \mathbf{U}$ & $\mathrm{G} \cdot \mathrm{C}^{a *}$ & $\mathrm{G} \cdot \mathrm{C}$ & $\mathrm{G} \cdot \mathrm{C}$ & $\begin{array}{l}\mathrm{A} \cdot \mathrm{U}: M . \text { adleri, } M . \text { columbinasale. } \\
\mathrm{G} \cdot \mathrm{U}: M . \text { fermentans }\end{array}$ \\
\hline $148 \cdot 174$ & $\mathrm{G} \cdot \mathrm{A}$ & $\mathbf{C} \cdot \mathbf{U}$ & $\mathrm{G} \cdot \mathrm{A}^{a}$ & $\mathrm{~A} \cdot \mathrm{G}, \mathrm{G} \cdot \mathrm{A}$ & $\mathrm{A} \cdot \mathrm{G}, \mathrm{G} \cdot \mathrm{A}$ & $\mathrm{C} \cdot \mathrm{U}:$ M. fermentans, $M$. bovigenitalium subcluster \\
\hline 152 & A & A & G & $\mathrm{A}, \mathrm{C}$ & A & G: haemotrophic mycoplasmas \\
\hline 169 & $\mathrm{C}$ & $\mathrm{C}$ & $\mathrm{A}^{a}$ & $\mathrm{C}, \mathrm{U}$ & $\mathrm{a}, \mathrm{C}, \mathrm{u}$ & $\mathrm{U}: M$. gallinarum \\
\hline $242 \cdot 284$ & $\mathrm{U} \cdot \mathrm{A}$ & $\mathrm{C} \cdot \mathrm{G}$ & $\mathrm{C} \cdot \mathrm{G}$ & $\mathrm{C} \cdot \mathrm{G}^{b}$ & $\mathrm{C} \cdot \mathrm{G}, \mathrm{U} \cdot \mathrm{A}, \mathrm{U} \cdot \mathrm{G}$ & $\mathrm{U} \cdot \mathrm{A}:$ M. sualvi, $M$. mobile \\
\hline 264 & $\mathrm{U}$ & $\mathrm{U}$ & $\mathrm{C}^{a}$ & $\mathrm{a}, \mathrm{U}$ & $\mathrm{A}, \mathrm{c}, \mathrm{U}$ & A: M. lipofaciens. U: M. iners, M. gallinarum \\
\hline $293 \cdot 304$ & $\mathrm{G} \cdot \mathrm{C}$ & $\mathrm{G} \cdot \mathrm{U}$ & $\mathrm{G} \cdot \mathrm{U}$ & $\mathrm{G} \cdot \mathrm{U}^{b}$ & $\mathrm{~A} \cdot \mathrm{U}, \mathrm{G} \cdot \mathrm{C}, \mathrm{G} \cdot \mathrm{U}, \mathrm{U} \cdot \mathrm{A}$ & $\mathrm{A} \cdot \mathrm{U}:{ }^{\prime} M$. agassizii', M. pulmonis, $M$. sturni \\
\hline 307 & $\mathrm{C}$ & $\mathrm{A}, \mathrm{U}$ & $\mathrm{A}, \mathrm{U}$ & $\mathrm{A}, \mathrm{U}^{b}$ & $\mathrm{~A}, \mathrm{c}, \mathrm{U}$ & C: M. gypis \\
\hline $407 \cdot 435$ & $\mathrm{~A} \cdot \mathrm{U}$ & $\mathrm{C} \cdot \mathrm{G}$ & $\mathrm{C} \cdot \mathrm{G}^{a}$ & $\mathrm{C} \cdot \mathrm{G}$ & $\mathrm{A} \cdot \mathrm{U}$ & $\mathrm{A} \cdot \mathrm{U}:$ M. fermentans subcluster \\
\hline $408 \cdot 434$ & $\mathrm{~A} \cdot \mathrm{U}$ & $\mathbf{C} \cdot \mathbf{G}$ & $\mathrm{A} \cdot \mathrm{U}$ & $\mathrm{A} \cdot \mathrm{U}$ & $\mathrm{A} \cdot \mathrm{U}, \mathrm{G} \cdot \mathrm{C}^{c}$ & $\mathrm{C} \cdot \mathrm{G}:$ Spiroplasma spp. (few) \\
\hline $409 \cdot 433$ & $\mathrm{C} \cdot \mathrm{G}$ & $\mathrm{U} \cdot \mathrm{G}$ & $\mathrm{G} \cdot \mathrm{C}$ & $\mathrm{C} \cdot \mathrm{G}, \mathrm{G} \cdot \mathrm{C}^{b}$ & $\mathrm{C} \cdot \mathrm{G}, \mathrm{G} \cdot \mathrm{C}, \mathrm{U} \cdot \mathrm{A}, \mathrm{U} \cdot \mathrm{G}$ & $\mathrm{U} \cdot \mathrm{G}:$ M. auris, M. buccale \\
\hline $417 \cdot 426$ & $\mathbf{C} \cdot \mathbf{G}$ & $\mathrm{A} \cdot \mathrm{U}, \mathrm{G} \cdot \mathrm{U}$ & $\mathrm{G} \cdot \mathrm{U}$ & $\mathrm{G} \cdot \mathrm{U}, \mathrm{U} \cdot \mathrm{A}$ & $\mathrm{G} \cdot \mathrm{U}, \mathrm{U} \cdot \mathrm{A}^{c}$ & $\begin{array}{l}\mathrm{C} \cdot \mathrm{G}: \text { Acholeplasma modicum, } \\
\text { Acholeplasma axanthum }\end{array}$ \\
\hline $446 \cdot 488$ & $\mathrm{~A} \cdot \mathrm{U}$ & $\mathrm{G} \cdot \mathrm{C}$ & $\mathrm{G} \cdot \mathrm{C}^{a}$ & $\mathrm{G} \cdot \mathrm{C}$ & $\mathrm{A} \cdot \mathrm{U}, \mathrm{G} \cdot \mathrm{C}$ & $\mathrm{A} \cdot \mathrm{U}:$ M. gallinarum. $\mathrm{U} \cdot \mathrm{G}:$ M. opalescens \\
\hline $501 \cdot 544$ & $\mathrm{U} \cdot \mathrm{A}$ & $\mathrm{C} \cdot \mathrm{G}$ & $\mathrm{C} \cdot \mathrm{G}$ & $\mathrm{C} \cdot \mathrm{G}^{b}$ & $\mathrm{C} \cdot \mathrm{G}, \mathrm{u} \cdot \mathrm{a}, \mathrm{u} \cdot \mathrm{g}$ & $\begin{array}{l}\mathrm{U} \cdot \mathrm{A}: \text { ' } M . \text { agassizii', M. sualvi. } \mathrm{U} \cdot \mathrm{G} \text { : } \\
\text { 'Candidatus Mycoplasma ravipulmonis', } \\
\text { M. ovipneumoniae }\end{array}$ \\
\hline 546 & $\mathrm{G}$ & A & A & A & $\mathrm{A}^{c}$ & $\begin{array}{l}\text { G: haemotrophic mycoplasmas, } \\
\text { mycoplasma-like organisms (some) }\end{array}$ \\
\hline $680 \cdot 710$ & $\mathrm{~A} \cdot \mathrm{U}$ & $\mathrm{C} \cdot \mathrm{G}$ & $\mathrm{C} \cdot \mathrm{G}$ & $\mathrm{C} \cdot \mathrm{G}, \mathrm{u} \cdot \mathrm{g}$ & $\mathrm{C} \cdot \mathrm{G}, \mathrm{u} \cdot \mathrm{g}^{c}$ & $\mathrm{~A} \cdot \mathrm{U}:$ M. fastidiosum cluster, haemotrophic mollicutes \\
\hline $771 \cdot 808$ & $\mathrm{G} \cdot \mathrm{C}$ & $\mathbf{A} \cdot \mathbf{U}$ & $\mathrm{G} \cdot \mathrm{C}$ & $\mathrm{G} \cdot \mathrm{C}$ & $\mathrm{G} \cdot \mathrm{C}^{c}$ & $\mathrm{~A} \cdot \mathrm{U}:$ mycoplasma-like organisms (few) \\
\hline 812 & $\mathrm{G}$ & G & $\mathrm{C}$ & $\mathrm{G}^{b}$ & $\mathrm{c}, \mathrm{G}$ & C: 'Candidatus M. ravipulmonis' \\
\hline 893 & $\mathrm{U}$ & $\mathrm{U}$ & $\mathrm{C}$ & $\mathrm{U}^{b}$ & $\mathrm{C}, \mathrm{U}$ & U: 'Candidatus M. ravipulmonis' \\
\hline $895 \cdot 904$ & $\mathrm{C} \cdot \mathrm{G}$ & $\mathrm{C} \cdot \mathrm{G}$ & $\mathrm{U} \cdot \mathrm{A}$ & $\mathrm{C} \cdot \mathrm{G}$ & $\mathrm{G} \cdot \mathrm{C}, \mathrm{U} \cdot \mathrm{A}$ & \\
\hline 906 & $\mathrm{G}$ & $\mathrm{G}$ & $\mathbf{A}$ & $\mathrm{G}^{b}$ & G & A: M. hominis, M. hyosynoviae \\
\hline $930 \cdot 1387$ & $\mathbf{U} \cdot \mathbf{A}$ & $\mathrm{C} \cdot \mathrm{G}$ & $\mathrm{C} \cdot \mathrm{G}, \mathrm{U} \cdot \mathrm{G}^{a}$ & $\mathrm{C} \cdot \mathrm{G}, \mathrm{U} \cdot \mathrm{G}$ & $\mathrm{C} \cdot \mathrm{G}, \mathrm{U} \cdot \mathrm{G}$ & $\mathrm{A} \cdot \mathrm{G}:$ M. californicum. $\mathrm{C} \cdot \mathrm{U}:$ M. simbae \\
\hline $1048 \cdot 1209$ & $\mathrm{G} \cdot \mathrm{U}$ & $\mathrm{A} \cdot \mathrm{U}$ & $\mathrm{A} \cdot \mathrm{U}$ & $\mathrm{A} \cdot \mathrm{U}$ & $\mathrm{G} \cdot \mathrm{C}$ & \\
\hline $1120 \cdot 1153$ & $\mathrm{~A} \cdot \mathrm{U}$ & $\mathrm{C} \cdot \mathrm{G}$ & $\mathrm{C} \cdot \mathrm{G}$ & $\mathrm{C} \cdot \mathrm{G}, \mathrm{U} \cdot \mathrm{A}$ & $\mathrm{a} \cdot \mathrm{u}, \mathrm{c} \cdot \mathrm{g}, \mathrm{G} \cdot \mathrm{C}, \mathrm{U} \cdot \mathrm{A}$ & \\
\hline $1124 \cdot 1149$ & $\mathrm{U} \cdot \mathrm{A}$ & $\mathrm{G} \cdot \mathrm{C}$ & $\mathrm{G} \cdot \mathrm{C}$ & $\mathrm{a} \cdot \mathrm{u}, \mathrm{G} \cdot \mathrm{C}^{b}$ & $\mathrm{a} \cdot \mathrm{u}, \mathrm{G} \cdot \mathrm{C}, \mathrm{G} \cdot \mathrm{U}$ & $\mathrm{U} \cdot \mathrm{A}:$ 'M. agassizii' \\
\hline $1129 \cdot 1143$ & $\mathrm{C} \cdot \mathrm{G}$ & $\mathrm{U} \cdot \mathrm{A}$ & $\mathrm{U} \cdot \mathrm{A}^{a}$ & $\mathrm{U} \cdot \mathrm{A}^{b}$ & $\mathrm{C} \cdot \mathrm{G}, \mathrm{U} \cdot \mathrm{A}$ & $\mathrm{C} \cdot \mathrm{G}:$ M. spermatophilum. $\mathrm{C} \cdot \mathrm{A}:{ }^{\prime} M$. agassizii' \\
\hline 1131 & $\mathrm{U}$ & - & $\mathrm{A}, \mathrm{C}$ &,$- \mathrm{A}$ & $\mathrm{A}, \mathrm{G}, \mathrm{U}$ & \\
\hline $1424 \cdot 1476$ & $\mathbf{A} \cdot \mathbf{U}$ & $\mathrm{U} \cdot \mathrm{A}$ & $\mathrm{U} \cdot \mathrm{A}$ & $\mathrm{U} \cdot \mathrm{A}, \mathrm{u} \cdot \mathrm{g}$ & $\mathrm{C} \cdot \mathrm{G}, \mathrm{g} \cdot \mathrm{u}, \mathrm{U} \cdot \mathrm{A}, \mathrm{U} \cdot \mathrm{G}^{c}$ & $\mathrm{~A} \cdot \mathrm{U}$ : haemotrophic mycoplasmas (few) \\
\hline $1436 \cdot 1465$ & $\mathrm{C} \cdot \mathrm{U}$ & $\mathrm{U} \cdot \mathrm{C}$ & $\mathrm{U} \cdot \mathrm{C}$ & $\mathrm{U} \cdot \mathrm{C}, \mathrm{A} \cdot \mathrm{U}, \overrightarrow{\mathrm{U}} \cdot \mathrm{U}^{b}$ & $\mathrm{~A} \cdot \mathrm{U}, \mathrm{C} \cdot \mathrm{A}, \mathrm{C} \cdot \mathrm{U}, \mathrm{U} \cdot \mathrm{A}$ & $\mathrm{C} \cdot \mathrm{U}:$ M. gypis, M. mobile \\
\hline
\end{tabular}


harbouring only two species. The current members, $M$. lipophilum $\mathrm{MaBy}^{\mathrm{T}}$ and $M$. hyopharyngis $\mathrm{H} 3-6 \mathrm{BF}^{\mathrm{T}}$, were $96.5 \%$ similar in $16 \mathrm{~S}$ rDNA sequence to each other, but only $\leqslant 93 \cdot 3, \leqslant 91.7$ and $\leqslant 88.8 \%$ similar to the neighbouring $M$. bovis, $M$. synoviae and $M$. equigenitalium clusters. It is notable that the value of $\leqslant 93.3 \%$ similarity to the $M$. bovis cluster approached the lower limit of the intraspecies 16S rDNA percentage similarity found among the individual members of the $M$. bovis cluster (see below). Despite this, the $M$. lipophilum cluster can be regarded as a separate phylogenetic unit as judged by the evolutionary distance tree and the presence of sequence signatures (Fig. 1; Table 2). This observation underlines the importance of performing phylogenetic computations instead of relying entirely on results obtained by simple similarity-based methods such as BLAST, which might be misleading.

Besides a marked and stable clustering in all derived trees, there are also $16 \mathrm{~S}$ rRNA gene sequence positions that are signatory for the M. lipophilum cluster (Table 2 ). Some compositions are found rarely in other bacterial phyla, such as the adjacently positioned base pairs $\mathrm{A} \cdot \mathrm{U}$ and $\mathrm{C} \cdot \mathrm{U}$ in positions $147 \cdot 175$ and $148 \cdot 174$. Exceptions to the former pair are found in the 16S rRNA molecules of six members of the Flavobacterium-Cytophaga-Bacteroides (FCB) phylum, including Blattabacterium. This composition is also present in Petrotoga miotherma, Fibrobacter succinogenes and Acetohalobium arabaticum. In the Archaea, the residues A.U at $147 \cdot 175$ are found only in a few halophiles and in Sulfolobus solfataricus and Sulfolobus shibatae. The feature $\mathrm{C} \cdot \mathrm{U}$ at position $148 \cdot 174$ is found in Mycoplasma fermentans and the Mycoplasma bovigenitalium subcluster (this study), as well as in Prevotella oralis and Isosphaera pallida in the domain Bacteria. It can also be found in some members of the domain Archaea. These positions are therefore likely to constitute suitable targets for probe-based diagnostic assays of the M. lipophilum cluster. Another very rare feature is the base pair $\mathrm{C} \cdot \mathrm{G}$ at $408 \cdot 434$, which is shared only by a few bacterial taxa and by four spiroplasmas among the mollicutes and occurs sparsely among the archaea. Furthermore, the $M$. lipophilum cluster has $\mathrm{A} \cdot \mathrm{U}$ at positions $771 \cdot 808$, shared with the order Chlamydiales and the genera Acinetobacter, Nocardiopsis, Arthrobacter and their relatives (most), Corynebacterium, Lactobacillus (most), the Actinomyces group (most), Actinopolyspora and a few other members of the Bacteria.

A higher-order structural feature was identified for the $M$. lipophilum cluster, namely a truncation of position 1131. However, this one-base deletion is also present in some members of the $\beta$-Proteobacteria, some spiroplasmas and the Clostridium leptum subgroup. It nevertheless constitutes a rarely observed attribute in the 16S rRNA molecule. The members of the pneumoniae group and the $M$. synoviae cluster have deletions in this region of several base pairs. Moreover, M. lipophilum $\mathrm{MaBy}^{\mathrm{T}}$ and $M$. hyopharyngis $\mathrm{H} 3-6 \mathrm{BF}^{\mathrm{T}}$ also share biochemical properties, in that both hydrolyse arginine but lack the ability to ferment glucose (Table 1).

\section{The $M$. bovis cluster}

The M. bovis cluster was found to contain 20 species, isolated from a variety of hosts (Table 1). Thus, this cluster is one of the largest entities of the hominis group, being about the size of the $M$. hominis cluster (Pettersson et al., 2000). The interspecies 16S rDNA similarities ranged between 91.9 and $99.5 \%$. Most of these values fell in the range $93-97 \%$, and only $9.5 \%$ of all the calculated percentage values in the distance matrix (190 in total) of this cluster fell outside this range. Typically, the $M$. bovis cluster was $\leqslant 92 \cdot 2 \%$ similar to the M. synoviae cluster and $\leqslant 89.1 \%$ similar to the $M$. equigenitalium cluster. Moreover, the $M$. bovis cluster could be divided further into a set of subclusters (detailed below), indicated in Fig. 1.

A sequence attribute, an adenosine residue, at position 906 can be found in other bacterial divisions, but occurs rarely among the Gram-positives with low $\mathrm{G}+\mathrm{C}$ content in their genomes. Therefore, this residue is shown in bold face, despite not having the status of a true signature.

All members of the M. bovis cluster, except Mycoplasma californicum, were found to have an extra nucleotide between positions 419 and 420 . This extra base will lead to the formation of a $C \cdot G$ base pair, thereby engaging the fourth nucleotide of the loop, starting at position 420 . The stem of this helix in the $M$. bovis cluster is therefore one base pair longer, due to a reduction of the tetra-loop found normally in this helix to a tri-loop. Mycoplasma meleagridis is characterized by having a non-canonical pair of the $\mathrm{U} \cdot \mathrm{G}$ type in the particular region of the $16 \mathrm{~S}$ rRNA molecule. Members of the FCB phylum, the Mycoplasma fastidiosum cluster and ureaplasmas of the pneumoniae group of the mollicutes also have a tri-loop in this part of the molecule.

\section{The $M$. equigenitalium cluster}

The two members of this cluster, M. equigenitalium strain $\mathrm{T} 37^{\mathrm{T}}$ and M. elephantis strain $\mathrm{E} 42^{\mathrm{T}}$, were found to be closely related, with a $16 \mathrm{~S}$ rDNA similarity of $99 \cdot 1 \%$. M. elephantis and M. equigenitalium showed a distinct line of descent, sharing a common ancestral node with members of the M. lipophilum, M. bovis and $M$. synoviae clusters. Generally, the M. equigenitalium cluster was $<90 \%$ similar to any other cluster or lineage within the hominis group, and its distinct position was justified from both the tree (Fig. 1) and nucleotide features (Table 2). A few of these were characterized as signatory for this cluster. One was observed to be the base pair $\mathrm{C} \cdot \mathrm{G}$ at $417 \cdot 426$, with only a few exceptions within the bacterial divisions such as the early bacterial lines Aquificales and 
Thermotogales, the genera Thermus and Fibrobacter and some environmental clones, Campylobacter and relatives and the subgroup of Thermoanaerobacter. Members of the Archaea have deletions in this region. The composition U.A at $930 \cdot 1387$ can be observed in subgroups of the FCB division, the spirochaete genus Leptospira, the Rickettsia and Orientia subgroups of the $\alpha$-Proteobacteria and the Calyptogena symbionts belonging to the Thiothrix nivea subgroup of the $\gamma$-Proteobacteria. Despite these exceptions, this feature is observed rarely in the domain Bacteria. A third attribute, the base pair $\mathrm{A} \cdot \mathrm{U}$ at positions 1424.1476, was observed in the Treponema pallidum subgroup, the genus Colwellia, Helicobacter and relatives, the Campylobacter fetus subgroup (Arcobacter and Sulfurospirillum) and the Haloanaerobium group. Two additional clusters also shared this composition, namely the Acetohalobium arabaticum and Alloiococcus otitis subgroups (three and two species, respectively).

\section{Subclusters within the $\boldsymbol{M}$. bovis cluster}

In general, the members of the M. bovis cluster showed a repeatedly stable topology in the different calculated phylogenies, which allows for the definition of subclusters (Fig. 1). Also, the subclusters were supported by high bootstrap percentage values of over $80 \%$. Nucleotide features that justify this fine-tuned classification, at least to a certain extent, have been compiled in Table 3. However, we believe that these subclusters should be regarded as tentative, because some of the subclusters predicted here might be destabilized as more taxa are added to the $M$. bovis cluster in future, with the need to re-evaluate them. Nevertheless, they will facilitate work significantly on the classification of organisms that are phylogenetically related to members of the $M$. bovis cluster. A short presentation, with the actual names of the subclusters and lines within the $M$. bovis cluster, follows below and the letter codes given in parentheses are the same as those used in Fig. 1 and Table 3. The names of the subclusters have been introduced by following the previously outlined scheme for phylogenetic grouping of the mycoplasmas by using binomial epithets (Pettersson $e t$ al., 2000).

Species $\boldsymbol{M}$. opalescens (a), $\boldsymbol{M}$. spermatophilum (f) and $\boldsymbol{M}$. lipofaciens (h). The species $M$. opalescens $\mathrm{MH} 5408^{\mathrm{T}}, M$. spermatophilum $\mathrm{AH} 159^{\mathrm{T}}$ and $M$. lipofaciens $\mathrm{R} 171^{\mathrm{T}} \mathrm{did}$ not cluster specifically with any other species in the $M$. bovis cluster and are defined as constituting singlespecies lines of descent. These species showed $16 \mathrm{~S}$ rDNA similarity of $\leqslant 96 \cdot 2 \%$ to each other or to any species of the other subclusters of the $M$. bovis cluster.

The Mycoplasma leopharyngis subcluster (b). The $M$. leopharyngis subcluster was supported by a bootstrap value of $100 \%$, containing $M$. leopharyngis $\mathrm{LL} 2^{\mathrm{T}}$ and M. maculosum $\mathrm{PG} 15^{\mathrm{T}}$. They were $99.5 \%$ similar at the $16 \mathrm{~S}$ rDNA sequence level and shared biochemical properties to some extent, in that both mycoplasmas do not ferment glucose (Table 1).

The Mycoplasma felifaucium subcluster (c). This entity harboured M. felifaucium $\mathrm{PU}^{\mathrm{T}}$ and Mycoplasma adleri G- $145^{\mathrm{T}}$, with a statistical bootstrap support of $100 \%$. They were $97.7 \%$ similar at the $16 \mathrm{~S}$ rDNA sequence level and shared biochemical properties (Table 1).

The $\boldsymbol{M}$. bovis subcluster (d). Three species formed the $M$. bovis subcluster, namely, M. bovis Donetta ${ }^{\mathrm{T}}$, Mycoplasma agalactiae $\mathrm{PG}^{\mathrm{T}}$ and $M$. primatum $\mathrm{HRC} 292^{\mathrm{T}}$. The 16S rRNA similarity ranged between 97.7 and $99.0 \%$ and all species are incapable of fermenting glucose (Table 1). They grouped together in $100 \%$ of the consensus and majority trees. Strikingly, this entity also showed a higher-order structural attribute in the 16S rRNA molecule, the insertion of a purine between positions 197 and 198 (E. coli). This feature is not present in other mollicutes (except $M$. hyopharyngis) or prokaryotes, thus being idiosyncratic for the $M$. bovis subcluster.

The $\boldsymbol{M}$. fermentans subcluster (e). M. fermentans $\mathrm{PG} 18^{\mathrm{T}}$ and $M$. caviae $\mathrm{G} 122^{\mathrm{T}}$ were constituents of the $M$. fermentans subcluster, grouping together with a bootstrap value of $100 \%$. Both species ferment glucose and their 16S rRNA gene sequences were $98.8 \%$ similar.

The $\boldsymbol{M}$. iners subcluster (g). With its five members, the $M$. iners subcluster was the largest phylogenetic subcluster in the $M$. bovis cluster. The members were $M$. iners $\mathrm{PG} 30^{\mathrm{T}}$, Mycoplasma gallinarum $\mathrm{PG} 16^{\mathrm{T}}, M$. meleagridis $17529^{\mathrm{T}}$, M. columbinasale $694^{\mathrm{T}}$ and $M$. columbinum MMP- $1^{\mathrm{T}}$. This clade was formed in as many as $80 \%$ of all trees that were obtained by 1000 resamplings of the data set. They only shared 16S rDNA similarities ranging between 94.0 and $96.4 \%$. These relatively low values suggest that they are separate species, without the need for the final justification of this status by performing DNA-DNA reassociation experiments (Stackebrandt \& Goebel, 1994). Phenotypically, all species are united by their capacity to hydrolyse arginine and their inability to ferment glucose. Interestingly, this was the only subcluster that shared the same group of hosts, i.e. all are of avian origin (Table 1).

The $\boldsymbol{M}$. bovigenitalium subcluster (i). $M$. bovigenitalium PG11 ${ }^{\mathrm{T}}, M$. californicum ST-6 ${ }^{\mathrm{T}}$ and Mycoplasma simbae $\mathrm{LX}^{\mathrm{T}}$ belonged to an entity that was termed the $M$. bovigenitalium subcluster. The primary structures of their 16S rRNA genes were $96 \cdot 0-97 \cdot 4 \%$ similar to each other. The branch of this subcluster was the most distinct, with a bootstrap support of $100 \%$. The three species are all unable to ferment glucose.

\section{Considerations on the clusters and subclusters for taxonomic work}

The updates and details of the part of the hominis group studied and discussed in this work will have a profound impact on taxonomic work on mollicutes belonging to the M. equigenitalium, M. lipophilum and 
Table 3 Unique and signature nucleotide positions in the 16S rRNA molecules of the different subclusters and lines within the M. bovis cluster

Letters a-i correspond to the subclusters and lines of descent indicated in Fig. 1. Unique nucleotide positions in the 16S rRNA genes of members of a particular subcluster are shown in bold. The letter codes $\mathrm{R}$ and $\mathrm{Y}$ follow the IUPAC code of the International Union of Biochemistry. Abbreviations for single-species lines and subclusters

correspond to the line of $M$. opalescens (Mopa), the M. leopharyngis (Mleo subcl.), M. felifaucium (Mfel subcl.), M. bovis (Mbovis subcl.) and M. fermentans (Mfer subcl.) subclusters, the line of M. spermatophilum (Mspe), the M. iners subcluster (Mine subcl.), the line of M. lipofaciens (Mlipof) and the M. bovigenitalium subcluster (Mbovig subcl.), as defined in the text and in Fig. 1. The numbers of particular positions correspond to those in the 16S rRNA molecule of E. coli (Brosius et al., 1978).

\begin{tabular}{|c|c|c|c|c|c|c|c|c|c|c|}
\hline $\begin{array}{l}\text { Position of base } \\
\text { or base pair }\end{array}$ & (a) Mopa & (b) Mleo subcl. & $\begin{array}{l}\text { (c) } \text { Mfel } \\
\text { subcl. }\end{array}$ & $\begin{array}{l}\text { (d) Mbovis } \\
\text { subcl. }\end{array}$ & $\begin{array}{l}\text { (e) } \text { Mfer } \\
\text { subcl. }\end{array}$ & (f) Mspe & $\begin{array}{l}\text { (g) Mine } \\
\text { subcl. }\end{array}$ & (h) Mlipof & $\begin{array}{l}\text { (i) Mbovig } \\
\text { subcl. }\end{array}$ & Comments* \\
\hline $82 \cdot 87$ & $\mathrm{~A} \cdot \mathrm{U}$ & $\mathrm{A} \cdot \mathrm{U}$ & $\mathrm{A} \cdot \mathrm{U}$ & $\mathrm{A} \cdot \mathrm{U}$ & $\mathrm{A} \cdot \mathrm{U}$ & $\mathrm{A} \cdot \mathrm{U}$ & $\mathrm{C} \cdot \mathrm{G}$ & $\mathrm{C} \cdot \mathrm{G}$ & $\mathrm{A} \cdot \mathrm{U}$ & \\
\hline 85 & A & A & A & A & A & A & $\mathrm{C}$ & $\mathrm{C}$ & $\mathrm{U}$ & \\
\hline $128 \cdot 233$ & $\mathrm{U} \cdot \mathrm{G}$ & $\mathrm{U} \cdot \mathrm{G}$ & $\mathrm{U} \cdot \mathrm{G}$ & $\mathrm{U} \cdot \mathbf{A}$ & $\mathrm{U} \cdot \mathrm{G}$ & $\mathrm{U} \cdot \mathrm{G}$ & $\mathrm{U} \cdot \mathrm{G}$ & $\mathrm{U} \cdot \mathrm{G}$ & $\mathrm{U} \cdot \mathrm{G}$ & $\begin{array}{l}\mathrm{U} \cdot \mathrm{A} \text { : hominis group (few), mollicutes } \\
(\text { few) }\end{array}$ \\
\hline $148 \cdot 174$ & $\mathrm{G} \cdot \mathrm{A}$ & $\mathrm{G} \cdot \mathrm{A}$ & $\mathrm{G} \cdot \mathrm{A}$ & $\mathrm{G} \cdot \mathrm{A}$ & $\mathrm{C} \cdot \mathrm{U}$ & $\mathrm{G} \cdot \mathrm{A}$ & $\mathrm{G} \cdot \mathrm{A}$ & $\mathrm{G} \cdot \mathrm{A}$ & $\mathrm{C} \cdot \mathrm{U} \dagger$ & $\mathrm{C} \cdot \mathrm{A}:$ M. simbae \\
\hline $154 \cdot 167$ & $\mathrm{G} \cdot \mathrm{C}$ & $\mathrm{U} \cdot \mathrm{G}$ & $\mathrm{G} \cdot \mathrm{C}$ & $\mathrm{G} \cdot \mathrm{C}$ & $\mathrm{G} \cdot \mathrm{C}$ & $\mathrm{A} \cdot \mathrm{U}$ & $\mathrm{A} \cdot \mathrm{U} \dagger$ & $\mathrm{A} \cdot \mathrm{U}$ & $\mathrm{G} \cdot \mathrm{C}$ & $\mathrm{G} \cdot \mathrm{C}:$ M. columbinum \\
\hline 183 & $\mathrm{U}$ & $\mathrm{U}$ & $\mathrm{U}$ & $\mathrm{U}$ & $\mathrm{U}$ & $\mathrm{U}$ & $\mathrm{G}$ & $\mathrm{C}$ & $\mathrm{U}$ & \\
\hline $200 \cdot 217$ & $\mathrm{~A} \cdot \mathrm{U}$ & $\mathrm{R} \cdot \mathrm{U}$ & $\mathrm{A} \cdot \mathrm{U}$ & $\mathrm{A} \cdot \mathrm{U}$ & $\mathrm{R} \cdot \mathrm{U}$ & $\mathrm{A} \cdot \mathrm{U}$ & $\mathrm{A} \cdot \mathrm{U}$ & $\mathrm{U} \cdot \mathrm{A}$ & $\mathbf{C} \cdot \mathbf{G}$ & $\mathrm{C} \cdot \mathrm{G}:$ M. hominis \\
\hline 305 & $\mathrm{G}$ & $\mathrm{G}$ & A & $\mathrm{G}$ & $\mathrm{G}$ & $\mathrm{G}$ & $\mathrm{G}$ & $\mathrm{G}$ & G & A: bacteria (few) \\
\hline $407 \cdot 435$ & $\mathrm{C} \cdot \mathrm{G}$ & $\mathrm{C} \cdot \mathrm{G}$ & $\mathrm{C} \cdot \mathrm{G}$ & $\mathrm{C} \cdot \mathrm{G}$ & $\mathbf{A} \cdot \mathbf{U}$ & $\mathrm{C} \cdot \mathrm{G}$ & $\mathrm{C} \cdot \mathrm{G}$ & $\mathrm{C} \cdot \mathrm{G}$ & $\mathrm{C} \cdot \mathrm{G}$ & $\mathrm{A} \cdot \mathrm{U}$ : hominis group (few) \\
\hline $443 \cdot 491$ & $\mathrm{~A} \cdot \mathrm{U}$ & $A \cdot U$ & $\mathrm{~A} \cdot \mathrm{U}$ & $\mathbf{U} \cdot \mathbf{G}$ & $\mathrm{R} \cdot \mathrm{U}$ & $\mathrm{A} \cdot \mathrm{U}$ & $\mathrm{A} \cdot \mathrm{U}$ & $A \cdot U$ & $A \cdot U$ & $\mathrm{U} \cdot \mathrm{G}$ : hominis group (few) \\
\hline $450 \cdot 483$ & $\mathrm{G} \cdot \mathrm{C}$ & $\mathrm{G} \cdot \mathrm{C}$ & $\mathrm{G} \cdot \mathrm{C}$ & $\mathrm{G} \cdot \mathrm{C}$ & $\mathrm{G} \cdot \mathrm{C}$ & $\mathrm{G} \cdot \mathrm{C}$ & $\mathrm{G} \cdot \mathrm{C}$ & $\mathrm{G} \cdot \mathrm{C}$ & $\mathbf{U} \cdot \mathbf{A}$ & $\mathrm{U} \cdot \mathrm{A}$ : mollicutes (few), bacteria (few) \\
\hline 484 & $\mathrm{G}$ & G & G & G & G & G & G & G & $\mathbf{U}$ & $\mathrm{U}$ : pneumoniae group, bacteria (few) \\
\hline $590 \cdot 649$ & $\mathrm{U} \cdot \mathrm{A}$ & $\mathrm{U} \cdot \mathrm{G}$ & $\mathrm{U} \cdot \mathrm{A}$ & $\mathrm{U} \cdot \mathrm{R}$ & $\mathrm{U} \cdot \mathrm{G}$ & $\mathrm{U} \cdot \mathrm{G}$ & $\mathrm{U} \cdot \mathbf{U}$ & $\mathrm{U} \cdot \mathrm{A}$ & $\mathrm{U} \cdot \mathrm{R}$ & $\mathrm{U} \cdot \mathrm{U}:$ hominis group (none) \\
\hline $659 \cdot 746$ & $\mathrm{~A} \cdot \mathrm{U}$ & $A \cdot U$ & $\mathrm{~A} \cdot \mathrm{U}$ & $A \cdot U$ & $\mathrm{G} \cdot \mathrm{U}$ & $\mathrm{A} \cdot \mathrm{U}$ & $\mathrm{A} \cdot \mathrm{U}$ & $A \cdot U$ & $\mathrm{~A} \cdot \mathrm{U}$ & \\
\hline 722 & A & $\mathbf{U}$ & A & A & A & A & A & A & A & $\mathrm{U}$ : hominis group (none) \\
\hline 819 & A & A & A & A & A & A & A & A & $\mathbf{U}$ & $\mathbf{U}$ : hominis group (few) \\
\hline $830 \cdot 856$ & $\mathrm{C} \cdot \mathrm{G}$ & $\mathrm{C} \cdot \mathrm{G}$ & $\mathrm{C} \cdot \mathrm{G}$ & $\mathrm{U} \cdot \mathrm{A}$ & $\mathrm{C} \cdot \mathrm{G}$ & $\mathrm{C} \cdot \mathrm{G}$ & $\mathrm{C} \cdot \mathrm{G}$ & $\mathrm{C} \cdot \mathrm{G}$ & $\mathrm{C} \cdot \mathrm{G}$ & \\
\hline $1163 \cdot 1173$ & $\mathrm{C} \cdot \mathrm{G}$ & $\mathrm{G} \cdot \mathrm{C}$ & $\mathrm{C} \cdot \mathrm{G}$ & $\mathrm{C} \cdot \mathrm{G}$ & $\mathrm{C} \cdot \mathrm{G}$ & $\mathrm{C} \cdot \mathrm{G}$ & $\mathrm{C} \cdot \mathrm{G}$ & $\mathrm{C} \cdot \mathrm{G}$ & $\mathrm{C} \cdot \mathrm{G}$ & \\
\hline $1243 \cdot 1294$ & $\mathrm{C} \cdot \mathrm{G}$ & $\mathrm{A} \cdot \mathrm{U}$ & $\mathrm{C} \cdot \mathrm{G}$ & $\mathrm{A} \cdot \mathrm{U}$ & $\mathrm{C} \cdot \mathrm{G}$ & $\mathrm{A} \cdot \mathrm{U}$ & $\mathrm{U} \cdot \mathrm{A}$ & $\mathrm{A} \cdot \mathrm{U}$ & $\mathrm{C} \cdot \mathrm{G}$ & \\
\hline $1254 \cdot 1283$ & $\mathrm{~A} \cdot \mathrm{U}$ & $\mathrm{A} \cdot \mathrm{U}$ & $\mathrm{A} \cdot \mathrm{U}$ & $\mathrm{A} \cdot \mathrm{U}$ & $\mathrm{A} \cdot \mathrm{U}$ & $\mathrm{A} \cdot \mathrm{U}$ & $\mathrm{A} \cdot \mathrm{U}$ & $\mathrm{A} \cdot \mathrm{U}$ & $\mathbf{Y} \cdot \mathbf{A}$ & $\mathrm{U} \cdot \mathrm{A}$ : hominis group (few) \\
\hline $1264 \cdot 1271$ & $\mathrm{U} \cdot \mathrm{A}$ & $\mathrm{U} \cdot \mathrm{A}$ & $\mathbf{A} \cdot \mathbf{U}$ & $\mathrm{U} \cdot \mathrm{A}$ & $\mathrm{U} \cdot \mathrm{A}$ & $\mathrm{U} \cdot \mathrm{A}$ & $\mathrm{U} \cdot \mathrm{A}$ & $\mathrm{U} \cdot \mathrm{A}$ & $\mathrm{U} \cdot \mathrm{A}$ & $\mathrm{A} \cdot \mathrm{U}$ : hominis group (none) \\
\hline 1273 & $\mathrm{G}$ & $\mathrm{C}$ & G & $\mathrm{G}$ & G & $\mathrm{G}$ & G & $\mathrm{G}$ & $\mathbf{U}, \mathbf{A}$ & $\mathrm{A}, \mathrm{U}$ : hominis group (few) \\
\hline 1274 & $\mathrm{G}$ & A & $\mathrm{G}$ & $\mathrm{G}$ & $\mathrm{G}$ & $\mathrm{G}$ & $\mathrm{G}$ & $\mathrm{G}$ & $\mathrm{G}, \mathrm{C}$ & \\
\hline $1310 \cdot 1327$ & $\mathrm{~A} \cdot \mathrm{U}$ & $\mathrm{A} \cdot \mathrm{U}$ & $\mathrm{A} \cdot \mathrm{U}$ & $\mathrm{A} \cdot \mathrm{U}$ & $\mathrm{U} \cdot \mathrm{A}$ & $\mathrm{U} \cdot \mathrm{A}$ & $\mathrm{U} \cdot \mathrm{A}$ & $\mathbf{U} \cdot \mathbf{A}$ & $\mathrm{G} \cdot \mathrm{C}$ & \\
\hline
\end{tabular}

* Comments are given as to what extent the actual nucleotide composition can be regarded as discriminatory.

$\dagger$ Taxa listed under comments are exceptions in nucleotide composition found among members of that particular subcluster. 
$M$. bovis clusters. In accordance with previous discussions on facilitating the classification of mycoplasmas (Heldtander et al., 1998; Johansson et al., 1998a; Pettersson et al., 1996, 2000), for a new mycoplasma strain that belongs phylogenetically to any of these clusters or subclusters, it should be sufficient to perform serological tests against the members of that cluster or subcluster. However, if the organism in question shows a 16S rDNA similarity of $>97 \%$ to another member(s) of the phylogenetic cluster or subcluster, but is serologically negative with antisera to this member, it is recommended that DNA-DNA hybridization experiments should be performed in order to reveal whether or not the organism should be given novel species status (Stackebrandt \& Goebel, 1994).

\section{ACKNOWLEDGEMENTS}

We are grateful to Marianne Persson and Ausi Boholm for valuable technical assistance. This work has been supported financially by grants from the Swedish Foundation for Strategic Research to B.P. and from the Research Foundation of SVA (National Veterinary Institute) to K.-E.J. The project forms a part of the EU research collaboration project COST 826 on 'Ruminants' Mycoplasmoses'.

\section{REFERENCES}

Armstrong, D., Tully, J. G., Yu, B., Morton, V., Friedman, M. H. \& Steger, L. (1970). Previously uncharacterized Mycoplasma isolates from an investigation of canine pneumonia. Infect Immun 1, 1-7.

Blank, W. A., Erickson, B. Z. \& Stemke, G. W. (1996). Phylogenetic relationships of the porcine mycoplasmas Mycoplasma hyosynoviae and Mycoplasma hyopharyngis. Int J Syst Bacteriol 46, 1181-1182.

Bölske, G. (1988). Survey of mycoplasma infections in cell cultures and a comparison of detection methods. Zentbl Bakteriol Hyg A 269, 331-340.

Boyle, J. S. \& Morrow, C. J. (1994). Phylogeny of avian mycoplasma: implications for mollicute taxonomy. IOM Lett $\mathbf{3}$, 589-590.

Bradbury, J. M., Forrest, M. \& Williams, A. (1983). Mycoplasma lipofaciens, a new species of avian origin. Int J Syst Bacteriol 33, 329-335.

Brosius, J., Palmer, M. L., Kennedy, P. J. \& Noller, H. F. (1978). Complete nucleotide sequence of a $16 \mathrm{~S}$ ribosomal RNA gene from Escherichia coli. Proc Natl Acad Sci U S A 75, 4801-4805.

Brown, D. R., McLaughlin, G. S. \& Brown, M. B. (1995). Taxonomy of the feline mycoplasmas Mycoplasma felifaucium, Mycoplasma feliminutum, Mycoplasma felis, Mycoplasma gateae, Mycoplasma leocaptivus, Mycoplasma leopharyngis, and Mycoplasma simbae by 16S rRNA gene sequence comparisons. Int J Syst Bacteriol 45, 560-564.

Clark, H. W., Bailey, J. S., Laughlin, D. C. \& Brown, T. M. (1978). Isolation of mycoplasmas from the genital tract of elephants. Zentbl Bakteriol Parasit Infekt Hyg Abt 1 Orig 241, 262.

DelGiudice, R. A., Carski, T. R., Barile, M. F., Lemcke, R. M. \& Tully, J. G. (1971). Proposal for classifying human strain Navel and related simian mycoplasmas as Mycoplasma primatum $\mathrm{sp}$. n. $J$ Bacteriol 108, 439-445.
Edward, D. G. ff. \& Fitzgerald, W. A. (1951). The isolation of organisms of the pleuropneumonia group from dogs. J Gen Microbiol 5, 566-575.

Edward, D. G. ff. \& Freundt, E. A. (1956). The classification and nomenclature of organisms of the pleuropneumonia group. $J$ Gen Microbiol 14, 197-207.

Edward, D. G. ff. \& Freundt, E. A. (1973). Type strains of species of the order Mycoplasmatales, including designation of neotypes for Mycoplasma mycoides subsp. mycoides, Mycoplasma agalactiae subsp. agalactiae, and Mycoplasma arthritidis. Int $J$ Syst Bacteriol 23, 55-61.

Edward, D. G. ff. \& Kanarek, A. D. (1960). Organisms of the pleuropneumonia group of avian origin: their classification into species. Ann NY Acad Sci 79, 696-702.

Felsenstein, J. (1993). PHYLIP: Phylogeny inference package (version 3.57). Department of Genetics, University of Washington, Seattle, WA, USA.

Gray, M. W., Sankoff, D. \& Cedergren, R. J. (1984). On the evolutionary descent of organisms and organelles: a global phylogeny based on a highly conserved structural core in small subunit ribosomal RNA. Nucleic Acids Res 12, 5837-5852.

Heldtander, M., Pettersson, B., Tully, J. G. \& Johansson, K.-E. (1998). Sequences of the 16S rRNA genes and phylogeny of the goat mycoplasmas Mycoplasma adleri, Mycoplasma auris, Mycoplasma cottewii and Mycoplasma yeatsii. Int J Syst Bacteriol 48, 263-268.

Hill, A. (1971). Mycoplasma caviae, a new species. J Gen Microbiol 65, 109-113.

Hill, A. C. (1991). Mycoplasma spermatophilum, a new species isolated from human spermatozoa and cervix. Int $J$ Syst Bacteriol 41, 229-233.

ICSB Subcommittee on the Taxonomy of Mollicutes (1995). Revised minimum standards for description of new species of the class Mollicutes (division Tenericutes). Int J Syst Bacteriol 45, 605-612.

Johansson, K.-E., Heldtander, M. U. K. \& Pettersson, B. (1998a). Characterization of mycoplasmas by PCR and sequence analysis with universal 16S rDNA primers. In Methods in Molecular Biology. Mycoplasma Protocols, vol. 104, pp. 145-165. Edited by R. J. Miles \& R. A. J. Nicholas. Totowa, NJ: Humana Press.

Johansson, K.-E., Persson, A. \& Persson, M. (1998b). Diagnosis of contagious caprine and contagious bovine pleuropneumonia by PCR and restriction enzyme analysis. In Towards Disease Control in the 21st Century, pp. 137-158. Vienna: International Atomic Energy Agency.

Jordan, F. T. W., Ernø, H., Cottew, G. S., Hinz, K. H. \& Stipkovits, L. (1982). Characterization and taxonomic description of five mycoplasma serovars (serotypes) of avian origin and their elevation to species rank and further evaluation of the taxonomic status of Mycoplasma synoviae. Int J Syst Bacteriol 32, $108-115$.

Jukes, T. H. \& Cantor, C. R. (1969). Evolution of protein molecules. In Mammalian Protein Metabolism, pp. 21-132. Edited by H. N. Munro. New York: Academic Press.

Kirchhoff, H. (1978). Mycoplasma equigenitalium, a new species from the cervix region of mares. Int $J$ Syst Bacteriol 28, 496-502.

Kirchhoff, H., Schmidt, R., Lehmann, H., Clark, H. W. \& Hill, A. C. (1996). Mycoplasma elephantis sp. nov., a new species from elephants. Int J Syst Bacteriol 46, 437-441.

Krabisch, P., Kirchhoff, H. \& von Lepel, J. F. (1973). Nachweis von 
Mykoplasmen auf Genitalschleimhäuten von Stuten. Dtsch Tierärztl Wochenschr 80, 493-495.

Lee, I.-M., Gundersen-Rindal, D. E., Davis, R. E. \& Bartoszyk, I. M. (1998). Revised classification scheme of phytoplasmas based on RFLP analyses of $16 \mathrm{~S}$ rRNA and ribosomal protein gene sequences. Int J Syst Bacteriol 48, 1153-1169.

Maniloff, J. (1992). Phylogeny of mycoplasmas. In Mycoplasmas: Molecular Biology and Pathogenesis, pp. 549-559. Edited by J. Maniloff, R. N. McElhaney, L. R. Finch \& J. B. Baseman. Washington, DC: American Society for Microbiology.

Pettersson, B., Uhlén, M. \& Johansson, K.-E. (1996). Phylogeny of some mycoplasmas from ruminants based on 16S rRNA sequences and definition of a new cluster within the hominis group. Int J Syst Bacteriol 46, 1093-1098.

Pettersson, B., Tully, J. G., Bölske, G. \& Johansson, K.-E. (2000). Updated phylogenetic description of the Mycoplasma hominis cluster (Weisburg et al. 1989) based on 16S rDNA sequences. Int J Syst Evol Microbiol 50, 291-301.

Rawadi, G., Dujeancourt-Henry, A., Lemercier, B. \& RoullandDussoix, D. (1998). Phylogenetic position of rare human mycoplasmas, Mycoplasma faucium, M. buccale, M. primatum and
M. spermatophilum, based on $16 \mathrm{~S}$ rRNA gene sequences. Int $J$ Syst Bacteriol 48, 305-309.

Rosendal, S. (1975). Canine mycoplasmas: serological studies of type and reference strains, with a proposal for the new species, Mycoplasma opalescens. Acta Pathol Microbiol Scand Sect B 83, 463-470.

Shimizu, T., Ernø, H. \& Nagatomo, H. (1978). Isolation and characterization of Mycoplasma columbinum and Mycoplasma columborale, two new species from pigeons. Int $J$ Syst Bacteriol 28, 538-546.

Smith, S. (1992). GDE: Genetic data environment, version 2.2. Millipore Imaging systems, Ann Arbor, MI, USA.

Stackebrandt, E. \& Goebel, B. M. (1994). Taxonomic note: a place for DNA-DNA reassociation and 16S rRNA sequence analysis in the present species definition in bacteriology. Int $J$ Syst Bacteriol 44, 846-849.

Weisburg, W. G., Tully, J. G., Rose, D. L. \& 9 other authors (1989). A phylogenetic analysis of the mycoplasmas: basis for their classification. J Bacteriol 171 6455-6467.

Yoder, H. W., Jr \& Hofstad, M. S. (1964). Characterization of avian mycoplasmas. Avian Dis 8, 481-512. 